\title{
Apakah Jenis Kelamin Memoderasi Pengaruh Harga Diri terhadap Perilaku Adiksi pada Instagram di Kalangan Remaja? ${ }^{1}$
}

\author{
Indah Mulyani, Hera Lestari Mikarsa, Ira Puspitawati
}

Fakultas Psikologi, Universitas Gunadarma

email: indah_mulyani@staff.gunadarma.ac.id

\begin{abstract}
Abstrak
Artikel INFO

Diterima:11 Feb 2020

Direvisi : 18 Feb 2020

Disetujui: 01 Mei 2020

DOI:

http://dx.doi.org/10.24014/ jp.v14i2.9221

Instagram merupakan media sosial yang paling populer di kalangan remaja saat ini. Penggunaan instagram secara terus menerus dapat menjadi potensi munculnya perilaku adiksi. Penelitian ini bertujuan untuk menguji secara empiris pengaruh harga diri terhadap adiksi pada instagram yang dimoderasi oleh jenis kelamin. Data diperoleh melalui skala adiksi pada instagram dan skala harga diri. Responden pada penelitian ini berjumlah 27 remaja yang sebelumnya berjumlah 285 kemudian disaring melalui tahap screening berdasarkan kriteria individu dengan adiksi menurut DSM-V. Analisis regresi moderasi digunakan untuk menguji hipotesis dalam penelitian ini. Hasil penelitian menunjukkan bahwa harga diri dan jenis kelamin memiliki pengaruh yang signifikan terhadap adiksi pada instagram. Hal ini dapat dikatakan bahwa baik laki-laki maupun perempuan memiliki peluang yang sama untuk terlibat dalam adiksi pada instagram meskipun berdasarkan hasil analisis deskripsi menunjukkan rerata skor adiksi instagram sedikit lebih tinggi pada remaja perempuan.
\end{abstract}

Kata kunci: Adiksi, Harga Diri, Instagram, Jenis Kelamin

\section{Does Gender Moderate the Effect of Self-Esteem on Instagram Addiction Behavior among Adolescents?}

\begin{abstract}
Instagram is the most populer social media among adolescents today. Continously instagram usage can be potential to emerge addiction behavior. This study was aimed to test the effect of self-esteem to instagram addiction moderated by gender. Data were collected using the instagram addiction scale and self-esteem scale. The subjects were 27 adolescents, who previously amount 285, filtered through screening phase based on criteria individual with addiction according to DSM-V. Moderated regression analysis was used to test the hypothesis. Data analysis showed that self-esteem had a significant effect to instagram addiction $(p<0.05)$, but not with gender. It said that both men and women have the same opportunities to engage in instagram addiction even though the results of descriptive analysis of instagram addiction show that mean scores slightly higher in women.
\end{abstract}

Keywords : Addcition, Gender, Instagram, Self-esteem

\section{Pendahuluan}

Hasil survey menyebutkan bahwa konten yang paling sering diakses saat menggunakan internet menunjukkan bahwa konten yang paling sering di akses adalah media sosial, yaitu sebesar $97,4 \%$ dari individu pengguna internet di Indonesia (APJII, 2016). Penggunaan media sosial yang terusmenerus atau berlebihan yang berpotensi menjadi perilaku adiksi tampaknya belum diangkat ke dalam pembahasan masalah klinis. Diagnostic and Statistical Manual of Mental Disorders-Fifth Edition (2013)

\footnotetext{
${ }^{1}$ Dipresentasikan dalam Seminar Nasional PascaSarjana di Universitas Gadjah Mada, Yogyakarta 23 Maret 2018
} 
memberikan catatan bahwa internet gaming disorder merupakan gangguan khusus diluar dari penggunaan internet untuk aktivitas yang memuat konten bisnis dan profesional, konten hiburan dan sosial, serta konten seksual. Pengecualian tersebut menunjukkan bahwa adiksi pada media sosial belum menjadi bagian dari gangguan mental.

Perilaku adiksi terhadap media sosial masuk ke dalam salah satu tipe perilaku adiksi internet, yaitu cyber-relationship addiction, karena tujuan dan motivasi utama untuk menggunakan media sosial adalah untuk membangun dan mempertahankan hubungan baik daring maupun non-daring (Kuss \& Griffiths, 2011). Andreassen (2015) mendefinisikan adiksi terhadap media sosial sebagai perilaku individu yang terlalu memperhatikan media sosial yang ia miliki, didorong oleh motivasi yang sangat kuat untuk masuk atau menggunakan media sosial, dan menghabiskan banyak waktu serta tenaga untuk bermain jejaring sosial sehingga mengganggu aktivitas sosial, pekerjaan/ akademik, hubungan interpersonal, serta kesejahteraan/kesehatan psikologis individu tersebut.

Griffiths dan Banyard (2005) menambahkan bahwa pengguna internet yang patalogis (penggunaan internet yang berlebihan) menyebabkan permasalahan akademis, sosial, dan interpersonal. Selain itu, mereka juga memiliki harga diri yang rendah. Harga diri adalah evaluasi individu mengenai nilai, kompetensi, dan keinginan diri individu (Konrath, 2012). Beberapa penelitian lain juga menyebutkan bahwa harga diri berkorelasi negatif dengan perilaku adiksi pada internet, yang artinya semakin tinggi kecenderungan individu untuk terlibat dalam perilaku adiksi berkaitan dengan rendahnya harga diri yang dimiliki oleh individu tersebut (Aydın \& Sarı, 2011; Fioravanti, De`ttore, \& Casale, 2012; Mei, Yau, Chai, Guo, \& Potenza, 2016; Pantic, Milanovic, Loboda, Blachnio, Przepiórka, Nesic, Mazic, Dugalic, \& Ristic, 2017).

Penelitian sebelumnya menjelaskan bahwa harga diri berkorelasi negatif dengan adiksi pada internet secara umum, dimana adiksi pada media sosial juga merupakan salah satu bentuk perilaku adiksi pada internet. Blachnio, Przepiórka, dan Pantic (2016) mencoba meneliti mengenai kaitan harga diri dengan perilaku adiksi pada Facebook, yang merupakan salah satu platform media sosial, menunjukkan hasil yang sama yaitu rendahnya harga diri berkaitan dengan adiksi pada Facebook. Selain rendahnya harga diri, variabel lain yang memprediksi perilaku adiksi pada media sosial adalah jenis kelamin. Adapun faktor demografis individu yang berkaitan dengan tingginya skor perilaku adiksi terhadap media sosial adalah individu yang berjenis kelamin perempuan (Andreassen, Pallesen, \& Griffiths, 2016). Hasil penelitian tersebut menguatkan bahwa perilaku adiksi terhadap media sosial menghambat evaluasi diri yang negatif serta mengindikasikan bahwa perempuan lebih cenderung untuk membangun perilaku adiktif terhadap aktivitas yang bersifat interaksi sosial dibandingkan laki-laki. Beberapa penelitian sebelumnya juga menunjukkan bahwa jenis kelamin merupakan variabel yang memoderasi hubungan variabel prediktor lain dengan perilaku adiksi internet (Chen, Zhang, Gong, Zhao, Lee, \& Liang, 2017; Yao, He, Ko, \& Pang, 2014).

Penelitian ini menggunakan remaja sebagai responden penelitian dikarenakan penelitian yang sebelumnya yang dipaparkan di atas menggunakan remaja sebagai responden penelitian. Selain itu, hasil survey menunjukkan bahwa $75,5 \%$ dari pengguna internet di Indonesia adalah usia remaja (APJII, 2016). Selanjutnya, peneliti memilih media sosial instagram untuk diangkat dalam penelitian ini dikarenakan instagram merupakan media sosial yang paling banyak diakses oleh remaja saat ini (Mulyani, Mikarsa, dan Puspitawati, 2018). Dilansir melalui www. suara.com (2019) diketahui bahwa pengguna instagram di Indonesia sebanyak 56 juta orang yang kemudian menempatkan Indonesia sebagai peringkat ke-empat untuk negara dengan jumlah pengguna instagram terbesar di dunia. Golbeck (2015) menyebutkan bahwa instagram merupakan salah satu aplikasi untuk membagikan gambar dimana para penggunanya mampu memberikan 
sentuhan artistik pada gambar tersebut dan mengunggahnya di instagram. Sentuhan artistik dalam fitur edit foto di instagram mampu menampilkan kualitas foto lebih baik dibandingkan hasil foto asli. Hal tersebut merupakan salah satu bentuk kompensasi bagi remaja dengan harga diri yang sehingga dapat menjadi alasan daya tarik khusus instagram yang membuat para penggunanya ingin terus menerus menggunakan instagram.

Penelitian ini bertujuan untuk menguji pengaruh harga diri terhadap adiksi pada instagram, dengan jenis kelamin sebagai moderator. Hipotesis yang dirumuskan dalam penelitian ini adalah pengaruh harga diri terhadap adiksi pada instagram dimoderatori oleh jenis kelamin. Penelitian ini merupakan bagian dari penelitian disertasi penulis mengenaimodel perilakuadiksipadainstagram di kalangan remaja. Adapun hipotesis dalam penelitian ini dapat digambarkan melalui perspektif cognitive-behavioral. Davis (2001) menjelaskan model cognitive-behavioral menggambarkan munculnya perilaku adiksi yang disebabkan karena adanya penyebab distal (stres, depresi, kecemasan sosial) dan proximal (kognisi maladaptif/distorsi kognitif, seperti rendahnya efikasi diri, selfdoubt, dan rendahnya penilaian diri) dalam kognitif individu yang kemudian diperkuat oleh adanya respon positif yang diperoleh saat menggunakan media sosial. Rendahnya penilaian diri remaja merupakan salah satu bentuk stres yang disebabkan oleh adanya penilaian negatif dalam hubungan teman sebaya. Seperti diketahui bahwa hubungan dengan teman sebaya mampu memengaruhi tingkat harga diri remaja (Aydin \& Sari, 2011).

\section{Metode}

\section{Subjek penelitian}

Subyek dalam penelitian ini adalah remaja yang berjumlah 285 orang $(74,4 \%$ remaja perempuan dan $25,6 \%$ remaja laki-laki) yang berusia 14-22 tahun berdomisili di daerah Jabodetabek sebagai responden penelitian. Subyek dalam penelitian ini merupakan pengguna aktif media sosial instagram sampai saat ini. Rata-rata responden telah menggunakan instagram selama 1-8 tahun.

\section{Pengukuran}

Instrumen penelitian ini menggunakan model skala Likert yang terdiri dari 6 respon jawaban. (1) Skala adiksi pada instagram terdiri dari 27 item yang diadaptasi melalui Eijnden, Lemmens, dan Valkenburg (2016) memiliki daya diskriminasi item 0,38-0,72 dan reliabilitas sebesar 0,94 . Salah satu item pada skala adiksi pada instagram adalah "Selama satu tahun belakangan ini saya mampu melupakan hal-hal yang tidak menyenangkan saat menggunakan instagram", (2) Skala harga diri terdiri 10 item yang diadaptasi melalui Rosenberg (1965) memiliki daya diskriminasi item 0,38-0,68 dan reliabilitas sebesar 0,82 . Salah satu item pada skala harga diri adalah "Saya merasa tidak memiliki banyak hal yang dapat dibanggakan".

\section{Analisis data}

Analisis data yang digunakan dalam penelitian ini adalah deskriptif statistik dan moderated regression analysis.

\section{Hasil}

Sebelum melakukan moderated regression analysis, peneliti menyaring remaja yang benar-benar terlibat adiksi instagram berdasarkan 285 data responden penelitian yang diperoleh. Penyaringan dilakukan dengan melihat individu yang memenuhi 5 dari 9 kriteria adiksi berdasarkan DSM-V (2013). Setiap kriteria diwakili oleh 3 item pernyataan sehingga item skaa adiksi pada instagram berjumlah 27 item. Setiap tiga item pernyataan dari masing-masing kriteria kemudian dihitung rerata responnya, apabila rerata respon bernilai $>3,5$ (di atas rata-rata mean hipotetik) maka remaja dapat dikatakan memenuhi 1 kriteria adiksi. Setelah itu, masing-masing responden memiliki skor kriteria yang kemudian respondne yang memiliki skor kriteria $\geq 5$ maka disaring sebagai responden yang terlibat adiksi pada instagram. Hasilnya diperoleh sekitar 9,5\% dari 285 responden terlibat dalam perilaku adiksi pada instagram. 
Tabel 1. Deskripsi Data Responden Penelitian

\begin{tabular}{lc}
\hline Kategori & Persentase \\
\hline Lama Bermain Instagram Setiap Harinya & \\
$<1$ jam per hari & $23,2 \%$ \\
1-3 jam per hari & $29,8 \%$ \\
$3-5$ jam per hari & $24,6 \%$ \\
5-8 jam per hari & $13,3 \%$ \\
$>8$ jam per hari & $9,1 \%$ \\
Aktivitas yang Paling Sering Dilakukan Saat & \\
Menggunakan Instagram & \\
Mengeksplor berbagai foto/video yang berkaitan dengan hobi/kesukaan & $37,5 \%$ \\
Melihat postingan instastory teman/user IG lain & $34,7 \%$ \\
Memposting foto/video pada insta story & $6 \%$ \\
Membaca berita dari akun IG berita online & $5,6 \%$ \\
Melihat akun teman/user IG lain melalui tools explore pada IG & $4,6 \%$ \\
Mengomentari/ memberikan love pada postingan teman/user IG lain & $3,9 \%$ \\
Mengirimkan pesan via direct message & $1,4 \%$ \\
Melakukan belanja online melalui akun IG belanja online & $1,1 \%$ \\
Memposting foto/video pada profil instagram & $0,7 \%$ \\
Melakukan insta live & - \\
Mengikuti insta live teman/user IG lain & - \\
Lainnya & $4,5 \%$ \\
\hline
\end{tabular}

Selain itu, hasil data deskriptif juga menunjukkan bahwa sebanyak $9,1 \%$ responden bermain instagram $>8$ jam per hari. Berdasarkan dua hasil deskripsi tersebut, dapat disimpulkan bahwa penggunaan instagram lebih dari 8 jam setiap harinya dapat memprediksi keterlibatan individu terhadap perilaku adiksi. Artinya, semakin sering remaja menggunakan instagram setiap harinya maka semakin tinggi kecenderungan remaja untuk terlibat ke dalam perilaku adiksi pada instagram. Hasil data deskriptif responden juga menunjukkan bahwa aktivitas yang paling sering dilakukan remaja saat menggunakan instagram adalah mengeksplor berbagai foto/video yang berkaitan dengan hobi/kesukaan kemudian diikuti dengan melihat postingan instastory teman/user instagram lain. Instastory merupakan salah satu tools dalam aplikasi instagram untuk sharing foto/video dengan batasan waktu untuk tampil. Aktivitas lainnya yang dilakukan remaja saat menggunakan instagram antara lain meneliti akun pro dan kontra presiden, memantau kegiatan teman dekat, melihat- lihat online shop/tempat wisata, melihat postingan yang berbau humor, dan melihat postingan artis korea. Hasil deskripsi data responden dapat dilihat pada tabel 1.

Hasil deskripsi data variabel penelitian pada responden menunjukkan bahwa skor adiksi pada instagram di kelompok remaja perempuan sedikit lebih tinggi dibandingkan remaja laki-laki begitu pula dengan rerata skor harga diri di kelompok remaja perempuan sedikit lebih tinggi dibandingkan remaja laki-laki. Hasil deskripsi variabel adiksi pada instagram per kriteria perilaku adiksi menunjukkan bahwa kriteria deception dan conflict berada pada kategori sangat rendah, kriteria preoccupation, tolerance, withdrawal, problem, dan displacement berada pada kategori rendah, serta kriteria persistence dan escape berada pada kategori sedang. Berdasarkan keseluruhan kriteria adiksi pada instagram, escpe memiliki rerata skor yang paling tinggi diantara kriteria lainnya. Hasil deskripsi data variabel penelitian dapat dilihat pada tabel 2. 
Tabel 2. Deskripsi Data Variabel Penelitian

\begin{tabular}{lccccc}
\hline \multirow{2}{*}{ Keterangan } & \multicolumn{5}{c}{ Skor Empirik } \\
\cline { 2 - 6 } & $\mathrm{n}$ & Min & Max & Rerata & SD \\
\hline Adiksi pada Instagram & 285 & 27 & 137 & 65,91 & 20,94 \\
Preoccupation & 285 & 3 & 18 & 7,38 & 3,13 \\
Tolerance & 285 & 3 & 18 & 7,71 & 3,29 \\
Withdrawal & 285 & 3 & 18 & 7,98 & 3,84 \\
Persistence & 285 & 3 & 18 & 8,87 & 3,77 \\
Escape & 285 & 3 & 18 & 11,9 & 3,71 \\
Problem & 285 & 3 & 16 & 6,28 & 2,88 \\
Deception & 285 & 3 & 15 & 5,01 & 2,34 \\
Dicplacement & 285 & 3 & 17 & 6,26 & 2,87 \\
Conflict & 285 & 3 & 12 & 4,53 & 1,90 \\
Adiksi pada Instagram (Laki-laki) & 73 & 27 & 137 & 63,34 & 22,49 \\
Adiksi pada Instagram (Perempuan) & 212 & 27 & 122 & 66,79 & 19,60 \\
Harga Diri & 285 & 21 & 54 & 38,48 & 6,63 \\
Harga Diri (Laki-Laki) & 73 & 21 & 51 & 37,52 & 6,91 \\
Harga Diri (Perempuan) & 212 & 21 & 54 & 38,82 & 6,52 \\
\hline
\end{tabular}

Tabel 3. Hasil Uji Hipotesis

\begin{tabular}{lcccc}
\hline Variabel Prediktor & $\mathrm{R}$ & $\mathrm{R}^{2}$ & $\mathrm{~F}$ & Sig. \\
\hline Harga Diri & $-0,128$ & 0,016 & 4,73 & 0,030 \\
Harga Diri, Jenis Kelamin, Produk & $-0,167$ & 0,028 & 2,68 & 0,047 \\
\hline
\end{tabular}

Hasil uji regresi dilakukan secara bertahap, tahap pertama dilakukan regresi linear antara skor harga diri dengan skor adiksi pada instagram. Hasil analisis menunjukkan $R^{2}$ sebesar 0,016 dan nilai $F$ sebesar $4,73 \quad(p<0,05)$ yang artinya harga diri berkontribusi sebesar $1,6 \%$ dalam memprediksi kecenderungan perilaku adiksi pada instagram. Hasil uji regresi menunjukkan bahwa harga diri mampu menjadi variabel prediktor yang sangat signifikan bagi remaja yang benar-benar terlibat dalam pola perilaku adiksi pada instagram. Setelah itu, uji regresi tahap dua dilakukan dengan uji ganda antara skor harga diri, jenis kelamin, dan produk secara bersama-sama dengan skor adiksi pada instagram. Skor produk diperoleh dengan mengalikan skor jenis kelamin dan skor harga diri. Hasil analisis menunjukkan bahwa, jenis kelamin merupakan variabel yang memoderasi pengaruh harga diri terhadap adiksi pada instagram. Hal ini ditunjukkan dengan meningkatnya nilai $\mathrm{R}^{2}$ menjadi 0,028 dengan nilai $F$ sebesar 2,68 $(p<0,05)$. Berdasarkan hasil analisis tersebut, dapat diperoleh kesimpulan bahwa hipotesis penelitian ini diterima. Jenis kelamin berperan sebagai variabel moderator terhadap pengaruh harga diri terhadap perilaku adiksi pada instagram di kalangan remaja.

\section{Pembahasan}

Hasil analisis statistik dalam penelitian ini menunjukkan bahwa harga diri merupakan variabel prediktor bagi perilaku adiksi pada instagram. Hal ini menunjukkan bahwa evaluasi yang negatif dari individu mengenai dirinya sendiri mampu berperan dalam membentuk perilaku adiksi pada instagram. Hasil penelitian ini mendukung literatur sebelumnya yang menyebutkan bahwa harga diri berkaitan dengan perilaku adiksi 
(Andreassen, Pallesen, \& Griffiths, 2016; Aydın \& Sarı, 2011; Blachnio, Przepiórka, \& Pantic, 2016; Fioravanti, De'ttore, \& Casale, 2012; Griffiths \& Banyard, 2005; Mei, Yau, Chai, Guo, \& Potenza, 2016; Pantic, Milanovic, Loboda, Blachnio, Przepiórka, Nesic, Mazic, Dugalic, \& Ristic, 2017). Seperti yang telah dipaparkan sebelumnya, bahwa perilaku adiksi instagram muncul akibat adanya penilaian diri yang negatif/rendah dari remaja yang dipengaruhi oleh kualitas hubungan dengan teman sebaya yang kemudian menyebabkan stres pada remaja. Instagram muncul sebagai media yang mampu memfasilitasi penggunanya (yang sebagian besar adalah remaja) untuk melepaskan stres tersebut atau dapat dikatakan sebagai sarana pelarian.

Salah satu perspektif psikologi yang mampu menjelaskan mengapa harga diri mampu berperan dalam keterlibatan individu terhadap adiksi instagram adalah cognitivebehavioral. Perspektif cognitive-behavioral muncul sebagai hasil kritik dari dua teori sebelumnya yaitu, behaviorism dan kognitif yang masing-masing teori terlalu menekankan pandangannya tersendiri dan menjelaskan bahwa perilaku adiksi terjadi akibat adanya kognisi maladaptif yang kemudian perilaku diperkuat dengan adanya proses operant conditioning melalui pengalaman yang diperoleh (Davis, 2001; Shek, Sun, \& Yu, 2013). Mai, Hu, Yan, Zhen, Wang, dan Zhang (2012) menjelaskan bahwa kognisi maladaptif merupakan bias kognitif yang dibentuk individu terhadap diri mereka sendiri dan dunia media sosial. Kognisi maladaptif dapat ditunjukkan dalam penilaian individu yang merasa dirinya lebih berharga dalam media sosial dibandingkan dalam dunia nyata. Shaw dan Black (2008) juga menyebutkan bahwa kognisi maladaptif, seperti meragukan diri sendiri, efikasi diri yang rendah, dan penilaian diri yang negatif, memegang peranan penting dalam pengembangan perilaku adiksi.

Hasil analisis deskriptif variabel menunjukkan bahwa rerata skor harga diri lebih besar pada kelompok remaja perempuan baik keseluruhan maupun yang terlibat adiksi pada instagram, meskipun tidak ada perbedaan yang signifikan dilihat dari selisih rerata skor yang kecil. Gentile, Grabe, Dolan-
Pascoe, Twenge, Wells, dan Maitino (2009) menjelaskan perbedaan harga diri antara laki-laki dan perempuan berdasarkan sepuluh domain harga diri. Hasilnya menunjukkan bahwa harga diri mengenai tampilan fisik, atletis, kepribadian, dan kepuasan akan diri pada laki-laki lebih besar sedangkan harga diri mengenai perilaku dan etika moral pada perempuan lebih besar. Selain itu ditemukan tidak ada perbedaan yang signifikan yang muncul pada harga diri mengenai akademis, penerimaan sosial, keluarga, dan afeksi.

Hasil analisis moderasi juga menunjukkan bahwa jenis kelamin memiliki fungsi moderasi dalam memperkuat pengaruh terhadap adiksi pada instagram. Artinya, jenis kelamin juga memiliki pengaruh terhadap perilaku adiksi dimana hal ini mendukung literatur sebelumnya yang menggunakan jenis kelamin sebagai variabel moderator dalam memperkuat pengaruh/hubungan terhadap perilaku adiksi (Andreassen, Pallesen, \& Griffiths, 2016; Chen, Zhang, Gong, Zhao, Lee, \& Liang, 2017; Yao, He, Ko, \& Pang, 2014). Perspektif biologis melihat bahwa beberapa gen terlibat dengan perilaku adiksi sedangkan beberapa lainnya terkait dengan kerentanan/kekebalan untuk terlibat dengan perilaku adiksi. Perbedaan gen pada laki-laki dan perempuan nampaknya menunjukkan adanya pengaruh dari jenis kelamin terhadap perilaku adiksi. Becker, McClellan, dan Reed (2017) menjelaskan bahwa perempuan lebih cenderung memperoleh pengalaman yang menyenangkan dari penggunaan substansi/non-substansi dan lebih cenderung untuk kambuh kembali dibandingkan lakilaki. Pada penelitian ini berarti remaja perempuan pengguna instagram akan lebih cenderung memperoleh pengalaman yang menyenangkan melalui instagram dimana hal tersebut merupakan salah satu pencetus perilaku adiksi pada instagram. Hal tersebut sesuai dengan hasil deskripsi data variabel penelitian pada responden secara keseluruhan menunjukkan bahwa skor adiksi pada instagram di kelompok remaja perempuan sedikit lebih tinggi dibandingkan remaja lakilaki dikarenakan remaja perempuan terlebih dahulu terlibat perilaku adiksi dibandingkan remaja laki-laki. 
Hasil temuan bahwa remaja perempuan cenderung memperoleh pengalaman yang menyenangkan sehingga memiliki skor adiksi yang sedikit lebih tinggi dibanding remaja laki-laki dapat dijelaskan melalui perspektif use and gratification. Perspektif use and gratification yang berangkat melalui keilmuan komunikasi menggambarkan bahwa individu memiliki dorongan yang berbeda-beda dalam tujuannya menggunakan media sosial. Kepuasan yang mereka peroleh dari penggunaan media sosial akan menjadikan penguatan perilaku penggunaan media sosial (Chen \& Kim, 2013; Oloo, 2013; Shao, 2009; Whiting \& Williams, 2013). Hasil temuan menunjukkan bahwa dorongan kebutuhan untuk mencari kesenangan (pleasure) diketahui berpengaruh paling besar terhadap adiksi instagram. Hal ini dikarenakan fitur dalam instagram mampu memfasilitasi penggunanya untuk mengakses gambar/ foto yang tak terbatas (Rahardjo, Andriani, Qomariyah, Hermita, \& Zanah, 2020). Murali dan George (2007) menjelaskan bahwa penggunaan instagram mampu menimbulkan perasaan senang dan euforia (gratification) pada penggunanya yang kemudian perilaku kecenderungan adiksi instagram muncul melalui prinsip operant conditioning.

Analisis deskriptif variabel per kriteria adiksi menunjukkan bahwa kriteria escape memiliki rerata skor pling besar diantara kriteria lainnya. Escape adalah salah satu kriteria adiksi yang menunjukkan perilaku individu yang menggunakan instagram dengan tujuan melarikan diri atau menghilangkan perasaan negatif, seperti rasa bersalah, cemas, ketidakberdayaan, dan sebagainya (Eijnden, Lemmens, \& Valkenburg, 2016). Andreassen (2015) menjelaskan bahwa individu menggunakan media sosial dengan tujuan mood modification atau untuk mengurangi perasaan bersalah, cemas, gelisah, tidak berdaya, depresi guna melupakan masalah pribadi. Perasaan cemas merupakan prediktor positif bagi perilaku adiksi pada media sosial lain (Koc \& Gulyagci, 2013). Individu yang cenderung mengalami perasaan cemas dikenal dengan individu dengan tipe kepribadian neuroticism (Costa \& McCrae, 1995). Umumnya individu yang mengalami adiksi adalah mereka yang mengalami kecemasan dalam berinteraksi sosial melalui tatap muka sehingga menggunakan instagram atau media sosial lainnya sebagai wadah dalam berinteraksi sosial tanpa harus bertatap muka langsung dengan orang lain. Penelitian Soliha (2015) menunjukkan bahwa kecemasan sosial pada individu berkaitan dengan tingkat ketergantungan penggunaan media sosial pada remaja. Penelitian lainnya secara langsung juga menjelaskan bahwa individu dengan tipe kepribadian neuroticism yang tinggi lebih sering terlibat dengan perilaku adiksi pada media sosial (Andreassen, Griffiths, Gjertsen, Krossbakken, Kvam, \& Pallesen, 2013; Balta, Emirtekin, Kircaburun, \& Griffiths, 2018; Marengo, Poletti, \& Settanni, 2019; Mulyani, Rahardjo, Citra, Damariyanti, Saputra, Ayuningsih, \& Siahay, 2017).

Selain itu, diketahui aktivitas yang paling sering dilakukan remaja saat menggunakan instagram adalah mengeksplor dan melihat foto/video yang teman/user IG lain serta foto/ video yang berkaitan dengan kesukaan/hobi mereka. Hal ini menyatakan bahwa remaja pengguna instagram lebih cenderung sebagai pengamat dalam instagram dibandingkan berkontribusi untuk membagikan foto/video mereka ke dalam instagram. Fenomena ini dikenal dengan istilah "lurking", yaitu individu yang hadir dalam ruang publik daring (media sosial) tetapi tidak menampilkan diri (Bolton dkk, 2013; Crawford, 2009). Namun perilaku lurking bergantung pada dimana individu berada dalam ruang publik daring, apakah berada dalam kelompok kerja atau kelompok sosial lain (Muller, 2012). Instagram merupakan salah satu bentuk ruang publik daring yang di dalamnya juga dapat memuat kelompok-kelompok soial lain. Pentingnya penilaian dari kelompok teman sebaya yang sama-sama menggunakan media sosial bagi evaluasi diri remaja nampaknya menjadi salah satu alasan remaja enggan untuk merespon dan lebih memilih untuk menjadi pengamat.

\section{Kesimpulan}

Berdasarkan hasil penelitian ini dapat disimpulkan bahwa setidaknya satu dari sepuluh remaja terlibat dalam perilaku adiksi terhadap instagram. Hal ini dapat dikarenakan instagram merupakan aplikasi yang mampu 
menutupi pemenuhan kebutuhan akan harga diri pada remaja secara signifikan seperti mengeksplorasi berbagai foto/video yang berkaitan dengan hobi/kesukaan yang mendominasi aktivitas yang paling sering dilakukan oleh remaja. Selain itu, diketahu pula bahawa remaja perempuan lebih rentan untuk terlibat adiksi dibandingkan dengan remaja laki-laki dikarenakan remaja perempuan lebih cenderung merasakan pengalaman yang menyenangkan dengan menggunakan instagram.

\section{Daftar Pustaka}

American Psychologist Association. (2013). Diagnostic and Ststistical Manual of Mental Disorder Fifth Edition. London : APA.

Andreassen, C.S. (2015). Online social network site addiction: A comprehensive review. Curr Addict Rep, 2, 175-184. DOI : 10.1007/s40429-015-0056-9

Andreassen, C.S., Pallesen, S., dan Griffiths, M.D. (2016). The relationship between addictive use of social media, narcissism, and self-esteem: Findings from a large national survey. Addicitive Behavior, DOI : 10.1016/j.addbeh.2016.03.006

Andreassen, Griffiths, Gjertsen, Krossbakken, Kvam, dan Pallesen. (2013). The relationships between behavioral addictions and the five-favtor model of personality. Journal of Behavioral Addiction, 2(2), 90-99. DOI: 10.1556/ JBA.2.2013.003

Asosiasi Pengguna Jasa Internet Indonesia. (2016). Infografis penetrasi dan perilaku pengguna internet Indonesia. Manuskrip Tidak Dipublikasikan Asosiasi Pengguna Jasa Internet Indonesia

Aydın, B. dan Sarı, S.V. (2011). Internet addiction among adolescents: The role of self-esteem. Procedia Social and Behavioral Sciences, 15, 3500-3505. DOI: 10.1016/j.sbspro.2011.04.325

Balta, S., Emirtekin, E., Kircaburun, K., \& Griffiths, M. D. (2018). Neuroticism, Trait Fear of Missing Out, and Phubbing: The Mediating Role of State Fear of Missing Out and Problematic Instagram Use. International Journal of Mental
Health and Addiction, 1-12 doi : https://doi. org/10.1007/s11469-018-9959-8.

Becker, J.B., McClellan, M.L., Reed, B.G. (2017). Sex differences, gender, and addiction. Journal of Neuroscience Research 95, 136-147. DOI: 10.1002/ jnr.23963

Blachnio, A. Przepiorka, A., dan Pantic, I. (2016). Association between facebook addiction, self-esteem and life satisfaction: A cross-sectional study. Computers in Human Behavior, 55, 701-705. DOI: http:// dx.doi.org/10.1016/j.chb.2015.10.026

Bolton, dkk. (2013). Understanding generation $y$ and their use of social media: A review and research agenda. Journal of Service Management, 24(3), 245-267. DOI: http:// dx.doi.org/10.1108/09564231311326987

Chen, C., Zhang, K.Z.K., Gong, X., Zhao, S.J., Lee, M.K.O., dan Liang. (2017). Examining the effects of motives and gender differences on smartphone addiction. Computers in Human Behavior, 75, 891-902. DOI: http://dx.doi. org/10.1016/j.chb.2017.07.002

Chen, H.T. \& Kim, Y. (2013). Problematic Use of Social Network Sites: The Interactive Relationship Between Gratifications Sought and Privacy Concerns. Cyberpsychology, Behavior, and Social Networking, 16(11), 806-812. DOI: 10.1089/cyber.2011.0608

Costa, P.T. dan McCrae, R.R. (1995). Persons, places, and personality: Career assessment using the revised NEO Personality Inventory. Journal of Career Assessment, 3(2), 123-139. DOI: 10.1177/106907279500300202

Crawford,K. (2009) Following you: Disciplines of listening in social media, Continuum: Journal of Media \& Cultural Studies, 23(4), 525-535. DOI: http://dx.doi. org/10.1080/10304310903003270

Davis, R.A. (2001). A cognitive-behavioral model on pathological internet use. Computers in Human Behavior, 17, 187 195.

Eijnden, Regina J.J.M., Lemmens, J.S., dan Valkenburg, P.M. (2016). The social media disorder scale. Computers in Human Behavior, 61, 478-487.

Fioravanti, G., De`ttore, D., dan Casale, S. 
(2012). Adolescent internet addiction: Testing the assocition between selfesteem, the perception of internet attributes, and preference for online social interaction. Cyberpsychology, Behavior, and Social Networking, 15(6), 318-323. DOI: 10.1089/cyber.2011.0358

Gentile, Grabe, Dolan-Pascoe, Twenge, Wells, dan Maitino. (2009). Gender differences in domain-spesific self-esteem: A metaanalysis. Review of General Psychology, 13(1), 34-45. DOI: 10.1037/a0013689

Golbeck, Jennifer. (2015). Introduction to social media investigation: A hands-on approach. USA: El-Sevier.

Koc, M. dan Gulyagci, S. (2013). Facebook addiction among turkish college students: The role of psychological health, demographic, and usage characteristics. Cyberpsychology \& Behavior, and Social Networking 16(4), 279-284.

Konrath, S. (2012, in press) Self-esteem, culturally defined. In Cultural Sociology of Mental IIIness: An A-to-Z Guide, Sage Reference

Kuss, Daria J dan Mark D. Griffiths. (2011). Online social networking and addiction A review of the psychological literature. International Journal of Environment Research and Public Health, 8, 35283552.

Mai, Y., Hu, J., Yan, Z., Zhen, S., Wang, S., \& Zhang, W. (2012). Structure and function of maladaptive cognitions in Pathological Internet Use among Chinese adolescents. Computers in Human Behavior, 28(6), 2376-2386. doi:10.1016/j.chb.2012.07.009

Marengo, D., Poletti, I., \& Settanni, M. (2019). The interplay between neuroticism, extraversion, and social media addiction in young adult Facebook users: Testing the mediating role of online activity using objective data. Addictive Behaviors, $106150 . \quad$ doi:10.1016/j. addbeh.2019.106150

Mei, S., Yau, Y.H.C., Chai, J., Guo, J. \& Potenza, M.N. (2016). Problematic internet use, well-being, self-esteem and self-control: Data from a highschool survey in China. Addictive Behaviors. DOI : 10.1016/j.addbeh.2016.05.009
Muller, M. (2012). Lurking as personal trait or situational disposition? Lurking and contributing in enterprise social media. Proceedings of the ACM 2012 conference on Computer Supported Cooperative Work, 253-256. DOI : https:// doi.org/10.1145/2145204.2145245

Mulyani, I., Mikarsa, H.L., \& Puspitawati, I. (2018). Perilaku Adiksi terhadap Instagram di Kalalangan Remaja. Artikel dipresentasikan pada Seminar Nasional PascaSarjana UGM, 23 Maret, Yogyakarta.

Mulyani, I., Rahardjo, W., Citra, A.F., Damariyanti, M., Saputra M., Ayuningsih A.M., dan Siahay, M. (2017). The Effect of Neuroticism and Loneliness to SNS Addiction on Social Media Users. Artikel dipresentasikan pada ARUPS Congress, 17 Oktober, Bali.

Murali, V. \& George, S. (2007). Lost online: An overview of internet addiction. Advances in Psychiatric Treatment, 13, 24-30 doi: 10.1192/apt.bp.106.002907

Niemz, K., Griffiths, M., dan Banyard, P. (2005). Prevalence of pathalogical internet use among university students and correlations with self-esteem, the general health questionnair (GHQ) and disinhibition. Cybepsychology \& Behavior, 8(6), 562-570.

Oloo, F.L. (2013). "Instagratification" : Uses and gratification of instagram by university students for interpersonal communication. Thesis (Unpublished). Communication and Media Studies, Eastern Mediterranean University

Oloo, F.L. (2013). "Instagratification" : Uses and gratification of instagram by university students for interpersonal communication. Thesis (Unpublished). Communication and Media Studies, Eastern Mediterranean University

Pantic, Milanovic, Loboda, Blachnio, Przepiórka, Nesic, Mazic, Dugalic, dan Ristic.(2017).Association between physiological oscillations in self-esteem, narcissism and internet addiction: A crosssectional study, Psychiatry Research. DOI: http://dx.doi.org/10.1016/j.psychres. 2017.08.044 
Pratnyawan, A. (2019). Pengguna instagram dan facebook Indonesia terbesar ke-4 di dunia. Dilansir melalui https://www.suara. com/tekno/2019/06/19/133252/penggunainstagram-dan-facebook-indonesia-terbesarke-4-di-dunia, Kamis, 20 Februari 2020.

Rahardjo, W., Andriani, I., Qomariyah, N., Hermita, M., \& Zanah, F.N. (2020). Adiksi media sosial pada remaja pengguna Instagram dan WhatsApp: Memahami peran need fulfillment dan social media engagement. Jurnal Psikologi Sosial, 18(1), 5-16.

Rosenberg, M. (1965). Society and the adolescent self-image. Princeton, $\mathrm{NJ}$ : Princeton University Press

Sariyska dkk. (2014). Self-esteem, personality and internet addiction: A cross-cultural comparison study. Personality and Individual Differences, 61, 28-33. DOI: http://dx.doi.org/10.1016/j.paid.2014.01.001.

Shao, G. (2009). Understanding the appeal of user-generated media: A uses and gratification perspective. Internet Research, 19(1), 7-25. DOI 10.1108/ 10662240910927795

Shao, G. (2009). Understanding the appeal of user-generated media: $A$ uses and gratification perspective. Internet Research, 19(1), 7-25. DOI 10.1108/10662240910927795

Shaw, M. \& Black, D.W. (2008). Internet addiction definition, assessment, epidemiology and clinical management. CNS Drugs, 22(5), 353-365 doi: 11727047/08/0005-0353/\$48.00/0

Shek,D.T.L., Sun, R.C.F., \& Yu, L. (2013). Neuroscience in the 21st century biomedical and life sciences. 2775-2811. DOI : 10.1007/978-1-4614-1997-6_108

Soliha, S.F. (2015). Tingkat ketergantungan pengguna media sosial \& kecemasan sosial. Jurnal Interaksi, 4(1), 1-10.

Whiting, A. \& Williams, D. (2013). Why people use social media: A uses and gratifications approach. Qualitative Market Research: An International Journal, 16(4), 362-369. DOI 10.1108/QMR-06-2013-0041

Whiting, A. \& Williams, D. (2013). Why people use social media: A uses and gratifications approach. Qualitative Market Research: An International Journal, 16(4), 362-369.
DOI 10.1108/QMR-06-2013-0041

Yao, M.Z., He, P., Ko, D.M., dan Pang, K. (2014). The influence of personality, parental behaviors, and self-esteem on internet addiction: A study of Chinese college students. Cyberpsychology, Behavior, and Social Networking, 17(2), 105-110. DOI: 10.1089/cyber.2012.0710 